\title{
OMNISCIENCE, IMMUTABILITY AND TENSED FACTS IN AVICENNA AND AL-GHAZÂLî
}

\author{
Abdulkadir Tanış \\ Hitit University
}

\begin{abstract}
In Islamic thought, the question "How does God know tensed facts?" has been thoroughly discussed over a tension between the attributes of omniscience and immutability. Avicenna and al-Ghazâlî, who give wide coverage to this problem in their studies, propose different solutions to eliminate this tension. Avicenna acknowledges that a being who knows tensed facts is subject to change, therefore he claims that God knows everything in a universal way and excludes tensed facts from the extent of omniscience. On the other hand, al-Ghazâlî claims that God knows tensed facts, but He does not undergo any real change by knowing them. In this study, I will argue that neither of these answers are convincing in generating a solution to the expressed tension.
\end{abstract}

Keywords: omniscience, immutability, Avicenna, al-Ghazâlî, tensed facts

DOI: https//doi.org/10.3176/tr.2021.3.05

Received 4 May 2021, accepted 5 August 2021, printed and available online 10 September 2021

\section{Introduction}

In Islamic thought, there is a consensus among philosophers of differing traditions that God is omniscient. However, there has been intense debate among these philosophers about how this omniscience should be understood. One of the issues that causes this controversy is on how He knows tensed facts. Although omniscience is accepted as a basic doctrine by the majority of philosophers, various views have been proposed regarding His way of knowing tensed facts. Avicenna (980-1037), 
who has a unique idea on this subject, puts forward that it is not appropriate to claim that God knows tensed facts in the same manner a temporal being does, lest His perfection be marred. His basic rationale for this claim is the idea that God, knowing tensed facts in such a way, will subject Him to change. Since change means a deficiency for God, a being that knows tensed facts cannot be perfect. Therefore, although God is omniscient, His way of knowing is different from that of a being in time. However, a compelling objection has been raised against this claim because it restricts the extent of God's knowledge. Al-Ghazâlî (1058-1111), who spearheaded this objection, argues that a God who does not know tensed facts will be unaware of what is happening in the universe and therefore cannot be regarded as omniscient. In this case, God would not be a perfect being since His knowledge would be lacking.

As known, in studies of Islamic philosophy, this discussion has been treated as a topic related to omniscience, and immutability has not been deliberated extensively. However, as Norman Kretzmann has effectively demonstrated with his article "Omniscience and immutability", the discussion seems to originate from a tension or incompatibility between the attributes of omniscience and immutability.

Therefore, in this study, I will deal with this discussion on God's knowledge of tensed facts in Islamic thought through this tension and examine the thoughts of Avicenna and al-Ghazâlî on the topic. For this, I will (i) evaluate their views on the reality of tensed facts and (ii) discuss their solutions to the tension and validity of these solutions. Taking his views into consideration, I will argue Avicenna's solution to the tension is limiting the omniscience attribute for the sake of immutability. In contrast, Ghazâlî attempts to preserve both omniscience and immutability and proposes that God knows tensed facts without changing. However, I will assert that he falls short of grounding his views on God knowing tensed facts without changing and fails to be persuasive.

\section{Tensed facts}

Our experience of events in a temporal succession is one of the fundamental phenomena of our daily life. This phenomenon refers to the experience of events as if they are constantly flowing from one point to another. Our experience of events in sequence manifests as the concept of tense. The emergence of the concept of tense stems from the classification of some events and objects as present and others as nonpresent, such as past and future. Accordingly, an event or an object is first designated as future, then present, and finally past. Without taking into account the temporal succession of what is present, it is not possible to become aware of objects and events that are non-present, such as the future and past. While objects and events that are happening at present are perceived directly, objects and events that do not exist at present are perceived based on some other mental states such as remembering and expectation (Tegtmeier 2014: 73-74).

This division of events and objects into present, past, and future categories has led to debates in terms of both linguistics and metaphysics. The main discussion on 
language is the question of whether there are tenses in all languages (see Dyke 2013: 328-332). Considering the languages of the world it is seen that most of them have tenses related to present, past, and future, or elements that fulfill this function. In terms of its function in the language, it is possible to define the tense as a 'grammaticalized expression of location in time' (Comrie 1985: 9). Thus, tenses function to determine the point in time in which events and objects are located.

From a metaphysical point of view, tenses have caused a rigorous debate about whether they are real or not. Especially McTaggart's (1866-1925) thoughts on time formed the basis of the discussions about the reality of tenses. According to McTaggart, it is possible to classify events in time in two ways: $A$-series and $B$-series. In the $A$-series, there is a relationship between events as present, past, and future, and this relationship is variable. In contrast, in the $B$-series, there is an 'earlier than' and 'later than' relationship between events, and this relationship is fixed (McTaggart 1908: 458-459). The debate on reality of tenses is directly related to the question of whether time is made up of the $A$ or $B$-series.

Proponents of the $A$-series version of time argue that distinctions such as present, past, and future exist independently of the observer and as a true quality of the world, and that time flows in a certain direction by this distinction. Accordingly, present has a privilege compared to other tenses. For now, passing from moment to moment, causes an event to be present when it is future and past when it is present. Therefore, the relations in the $A$-series can be said to be dynamic. On the other hand, proponents of the $B$-series version of time argue that present, future, and past distinctions we make between events do not have any correspondence to reality and that they stem from our perception of events. Since there is no such distinction between events in reality, there is no point in saying that there is a temporal flow, and that present is in a privileged position. Thus, past and future are as real as present, and there is a static rather than a dynamic relationship between events (Dyke 2013: 332-336, Swinburne 1990: 117-118).

The main reasoning that the $A$-theorists who defend the reality of tenses use to support their claim is that tense is an irreducible feature of our daily language. The irreducibility of tenses shows that reality is also tensed. For when we eliminate these tenses from our language, there is a significant loss of meaning. $B$-theorists respond by stating that tensed facts can be expressed tenselessly without any loss of meaning. That is to say, it is possible to replace tensed expressions with tenseless ones which have the same meaning and thus, to de-tense ordinary language (Dyke 2013: 336-338). "However," as Dyke stated, "in the 1960s and 1970s, work by various philosophers of language showed that it is not possible to de-tense language without losing the ability to convey certain information... In other words, linguistic tense, considered in the wider sense of any linguistic means of locating events in the A-series, is an essential feature of language" (Dyke 2013: 338-339). 


\section{Can God know tensed facts?}

Considering the profound debates within the theist tradition about how God knows tensed facts, it is possible to say that the above discussion of tensed facts has a notable counterpart in the philosophy of religion literature. One of the most striking examples of this is the claim that an incompatibility or tension arises between certain attributes of God, especially between omniscience and immutability, if he knows tensed facts. As it is known, classically, there is largely a consensus within theist tradition that God is both all-knowing and immutable. However, in the contemporary philosophy of religion, with the article "Omniscience and Immutability" by N. Kretzmann, it has been generally stated that these two attributes are incompatible (Kretzmann 1966). His argument is essentially based on the claim that a God who knows the flow in the universe cannot be immutable. Leftow formulates Kretzmann's argument as follows:

1. If God is omniscient, God knows what time it is now.

2. What time it is now is constantly changing. So

3. what God knows is constantly changing. (First, He knows that it is now $t$ and not now $t+1$, later He knows that it is now $t+1$ and not now $t$.) So

4. God is constantly changing (Leftow 2016).

According to the argument, it is inconsistent to say on the one hand that God is all-knowing, and on the other hand, He does not change in any way. As a result, if God knows everything, then he must know what time it is now. However, because time is constantly changing, if God knows what time it is, He also undergoes a change. For God, who knows what time it is, will know that now is $t$, but after a minute he will know that it is $t+1$, and His knowledge will be changing as the change continues in this way. In this case, if God knows everything and thus knows what time it is, it will not be possible to argue that He is immutable. On the other hand, if it is acknowledged that God is immutable, it will be hard to claim that He is omniscient. Therefore, it seems that there is an incompatibility or tension between omniscience and immutability.

The incompatibility or tension, which Kretzmann claims to exist between omniscience and immutability, has been widely discussed in Islamic philosophy over God's knowledge of tensed facts. According to Leftow, the argument reformulated by Kretzmann was put forward in al-Ghazâlî's famous work The Incoherence of the Philosophers (Leftow 2016). However, in the discussions on Islamic philosophy, the subject has been rather shaped around omniscience, and as a result, knowledge regarding tensed facts has been discussed only in the context of absolute knowledge, and immutability has not been brought up much. But when the content of the debate put forward by Islamic philosophers is examined, it will be noted that the subject is discussed over the tension between immutability and omniscience. This point can be seen in the following passage where al-Ghazâlî tries to explain the tension with the example of a solar eclipse, an example frequently used in Islamic philosophy: 
We will explain this with an example - namely, that the sun, for example, becomes eclipsed after not being eclipsed, then becomes bright again. Three things occur to it - I mean to the eclipse: (1) A state in which it is nonexistent, but its existence is expected - that is, it will be; (2) a state in which it exists - that is, it is; (3) a third state in which it is nonexistent, having, however, been previously existent. Alongside these three states, we have three different cognitions. For we know, first of all, that the eclipse is nonexistent but will be; secondly, that it is; and, thirdly, that it was but is not presently existing. These three cognitions are numbered and different. Their succession over the [one] receptacle necessitates a change in the knowing essence. For, if, after the clearing [of the eclipse], one were to 'know' that the eclipse presently exists, this would be ignorance, not knowledge; and if, when [the eclipse actually] exists, one were to 'know' that it does not exist, this [also] would be ignorance [and not knowledge]. For none of [these states] can take the place of the other (Al-Ghazâlî 2000: 134-135).

As can be seen in this quote, the concepts of knowledge and change are at the heart of the problem. Accordingly, we know facts only in a tensed way due to the successive emergence of events. However, our knowledge about tensed facts changes with the flow of time. Since such a way of knowing is dependent on time, tenses change with the flow of time, and as a result, our knowledge about it also changes. Considering this fact about human knowledge, al-Ghazâlî discusses God's knowledge about tensed facts in the context of omniscience and immutability in the remainder of the text with reference to philosophers such as Avicenna and al-Farabi. This discussion shows that the tension which Kretzmann points out regarding omniscience and immutability has been thoroughly studied in Islamic thought. However, it should be noted that Islamic philosophers point to the problem in terms of tensed expressions, while Kretzmann rather points to the problem in terms of what time it is. Therefore, we can say that there is prima facie a considerable difference between them. Even if this point is correct, the same idea lies in the background of the claim that there is a tension between these two attributes in both Islamic philosophers and Kretzmann: the flow of time.

The discussion of God's knowledge of tensed facts is based on the question of how a timeless and immutable being knows the universe which is in a constant flow and change. The solutions put forward on this issue seem to depend to a large extent on the attitude one has towards the reality of tenses. As Craig stated, if the $A$ theory of time is correct, then with the flow of time, tensed facts will have a reality and therefore God will have to know these facts. Since tensed facts are constantly changing, the conclusion will be that a God who knows them is also temporal and mutable in this respect.

But if the $B$ theory of time is correct, then temporal flow is an illusion and tensed facts do not exist. In this case, there is no problem as it is possible for God to know everything with no reference to tenses. According to Craig, "The B-theorist escapes 
this argument by denying that there are any tensed facts... The B-theorist holds that God knows all the facts there are about the temporal world in knowing tenseless facts" (Craig 2000: 226). Therefore, the alleged incompatibility between omniscience and immutability seemingly arises when the $A$ theory of time is acknowledged. For when the $A$ theory of time is acknowledged, the reality of dynamic temporal flow and tensed facts in the universe is also admitted. Therefore, if God is to be truly omniscient, He must know these tensed facts as they are, that is, with their state over change, and is consequently subject to change. However, if the $B$ theory of time is accepted, since the facts that we express in a tensed way will be considered to be tenseless and static, there will be no problem in God's knowing them.

\section{Two different solutions: Avicenna and al-Ghazâlî}

What claims do Avicenna and al-Ghazâlî make about God's knowledge of tensed facts? The basic thesis of Avicenna is that God 'apprehends intellectually all things in a universal way' (Avicenna 2005: 288), including tensed facts. In his thesis, the expression 'in a universal way' which means God's way of knowing, has a key role, and must be clarified. So how should we understand this expression? It is possible to interpret this thesis, that God knows everything in a universal way, through two claims: one negative and one positive. According to the negative claim, which means what kind of knowledge God cannot have, God cannot know tensed expressions as they are, that is, in their changing state. Avicenna emphasizes this point as follows:

In another respect, it is not possible that $\mathrm{He}$ would apprehend intellectually these changeable with the changes [they undergo] (since they are changeable) in a temporal, individualized manner... (Avicenna 2005: 287).

Therefore the knowledge that whose existence is necessary has of particular things must not be temporal knowledge such that it includes the present, the past, and the future... (Avicenna 2014: 177).

According to Avicenna, God does not know the particulars ${ }^{1}$ that are in time as things that are divided into tenses and change with the flow of the present. Therefore, in the philosophy of Avicenna, it does not seem possible to say that God knows tensed facts that imply change.

So why does God not know tensed facts as they are in time? At least three reasons can be given for this. First, since God 'is pure intellect because He is an essence dissociated from the matter in every respect' (Avicenna 2005: 284), He cannot know changeable things in their changing states. The reason for this is that changeable

\footnotetext{
1 As Marmura stated, "For the expression, 'particulars' (al-juz'iyyât), in Avicenna refers not only to things or entities, but also to events (including those enacted by men) - past, present and future" (Marmura 1985: 82). For this point also see Leaman 2004: 133. In this study, I deal with the concept of particulars with reference to past, present and future.
} 
things are of matter and these things are perceived only through an organ (Afnan 2016: 110-111, Avicenna 2005: 287, Leaman, 2004: 132, 140). It is out of the question for God to have such an organ and sensory apprehension. Second, God's knowledge of changing things does not originate from these things. For if these changing beings were the cause of God's knowledge, then God would depend in some way on a being other than himself, and He would not be a Necessary Existent (Avicenna 2005: 287). ${ }^{2}$

The third and main reason why God does not know tensed facts is that if He knows them, he will be subject to change. As stated above, the facts expressed in tenses are assumed to be in a continuous change. Evaluating the example of a solar eclipse, let's assume that the sun will become eclipsed tomorrow. In this case, the proposition 'The sun will become eclipsed tomorrow' is correct. During the eclipse, the proposition 'The sun is becoming eclipsed now' is true and the previous proposition is false. One day after the eclipse ends, the proposition 'The sun became eclipsed yesterday' will be true and the previous two propositions will be false. According to Avicenna, it is out of the question for God to know such varying tensed facts:

It is not possible that at one instance in a temporal [act] of intellectual apprehension He would apprehend them as existing, not non-existing, and at another instance [in a state of] nothingness, non-existing. For then each of the two situations would have an intellectual concept apart from the other, neither of the two concepts remaining with the other and thus the Necessary Existent would be of a changeable essence (Avicenna 2005: 287).

To evaluate these ideas in terms of the example of a solar eclipse, if God knows the eclipse in a tensed way, He would be of a changeable essence. For moving from the proposition 'The sun will become eclipsed tomorrow' to the proposition 'The sun is becoming eclipsed now' means a change in the person who knows these propositions. This is because it is admitted that while a solar eclipse does not exist in the first proposition, it does so in the latter proposition. This implies a change in the person who knows tensed facts. Thus, since change is considered a deficiency for the perfection of God, according to Avicenna, it is not possible for Him to know tensed facts.

The positive claim, which means what kind of knowledge God has, can be explained by two basic characteristics: His knowledge is unchangeable, and it is one knowledge. First, the unchanging nature of God's knowledge stems from the fact that this knowledge is 'conceptual' or 'intellectual' in nature (Adamson 2005: 261-268, Marmura 1962: 301). The term intellectual is used as the opposite of the concept of sensible, which refers to the world of changing beings. Sensation

2 We can say that being a Necessary Existent is also one of the reasons for immutability because in that Existent there is no unrealized possibilities. As Adamson pointed out, "for Avicenna God cannot change, because everything about Him is necessary. In order for a thing to change, it has to be possible for that thing to be different, but with God there are no as-yet-unrealized possibilities, there is only necessity" (Adamson 2016: 132). 
refers to the way of knowing a being in time does. In contrast, God, being a pure intellect, does not need this kind of sensation to know. As implied by the expression knowing in a universal way, His knowledge is free from any change. For, as we have just stated, beings in time and change cannot be the cause of God's knowledge. On the contrary, as a more important point, God's knowledge is the cause of these beings. According to Avicenna, God 'must know everything because everything is a necessary consequence of him...' (Avicenna 2014: 177). In this way, since God is the cause of all existence, when He apprehends His essence, He has all knowledge about existence. Avicenna reveals this as follows:

When He intellectually apprehends His essence and apprehends that $\mathrm{He}$ is the principle of every existent, He apprehends the principles of the existents [that proceed] from Him and what is generated by them. There is, among the things that exist, nothing that is not in some manner necessitated by Him [as] cause-this we have shown. The collision of these causes results in the existence of particular things. The first knows the causes and their corresponding [relations]. He thus necessarily knows to what these lead, the time [intervals] between them, and their recurrences. For it is not possible that He knows [the former principles] and not this. He would thus apprehend particular things since they are universal - I mean since they have attributes (Avicenna 2005: 288).

These statements bring us to the most controversial point of Avicenna's thesis. When we consider these expressions together with those stated above, according to him, God does not know the particular beings that live in time and tensed facts related to them, but He knows them universally. When considered in this way, many critics, especially al-Ghazâlî, claim that this thesis renders God unaware of the events happening in the universe (Burrell 1986: 81-83, Fakhyr 2004: 158-159, Marmura 1962: 304). Contrary to this claim, Avicenna says 'no individual thing escapes His knowledge, although this is how God's knowledge is. Not [even] the weight of an atom in the heavens and the earth escapes Him' (Avicenna 2005: 288). ${ }^{3}$ Since this is the most controversial point of the thesis of knowing in a universal way, we will reconsider it when we deal with al-Ghazâlî's discussion of the matter.

Second, the claim to know in a universal way requires God to know everything by one knowledge. According to Avicenna, it would mean a deficiency in God to acknowledge that there are many mental actions in God in terms of knowing, as attributing many actions to God leads to a deficiency in Him (Avicenna 2005: 288). To suppose of such a thing for God will lead to a multiplicity in His substance. However, to preserve the perfection of God, there should not be various or

3 Avicenna here makes a reference to a verse of Qur'an (34/3) to emphasize that even if God knows everything in a universal way, he also knows the particulars. Ironically, al-Ghazâlî uses the same verse to criticize Avicenna's understanding of omniscience as follows: "The second question is their declaration: 'God Most High knows universals, but not particulars'. This also is out-and-out unbelief. On the contrary, the truth is that 'there does not escape Him the weight of an atom in the heavens or in the earth"” (Al-Ghazâlî 1980: 76-77). 
differentiated forms in Him (Adamson 2016: 132, Leaman 2004: 133). Thus, 'He intellectually apprehends things all at once...' (Avicenna 2005: 291). In other words, knowledge of God consists of one knowledge in which there are no different forms or different mental insights.

To evaluate the thoughts of Avicenna expressed so far, it can be concluded that he admits the reality of tensed facts in the discussion on their ontology. We can give two reasons to show that Avicenna acknowledges the reality of tensed facts. First, he indirectly confirms the reality of tensed facts by claiming that God will be subject to change if He knows tensed facts. Otherwise, since tenses and change would not have a reality, God should not be subject to any change when he knows them, and consequently these would not cause problems for His knowledge. However, since Avicenna accepts their reality, he concludes that God will be subject to change by knowing them. Second, given his further work, it seems that he adheres to the reality of time and a flow in the universe (See Afnan 2016: 213-216, Avicenna 2009: 229236). As for the tension between omniscience and immutability, because Avicenna accepts the reality of tensed facts, he thinks that knowledge of these will lead to a change in God. Based on this, he tries to overcome the tension by eliminating knowledge of tensed facts from the extent of omniscience and consequently, he restricts the extent of God's knowledge by acknowledging immutability as more important to God's perfection.

At this point, al-Ghazâlî strongly opposes Avicenna's thesis by many serious criticisms. According to al-Ghazâlî, although the basis for defending such theses is an effort to preserve God's perfection, this ultimately results in the rejection of everything that can be considered as perfection for God. This makes God completely unaware of what is happening in the universe (Al-Ghazâlî 2000: 70-71). As Campanini pointed out, "The Qur'anic God [which al-Ghazâlî acknowledges this concept of God] is a person, knowing, willing, powerful, creating, judging, acting everywhere and in every time, while the philosophers' God is far away, remote and separate, almost indifferent or even unaware, or worst still, ignorant of what happens in nature and in the human world" (Campanini 2019: 123). To preserve immutability and thus the perfection of God, Avicenna cuts off God's relationship from the being in change. And he thinks that in this way, he guarantees His perfection because assuming that God has a direct relationship with the changing universe is regarded as a deficiency for Him. However, keeping God away from the temporal world in this way to preserve His perfection makes Him unaware of what is going on in the universe.

Of course, it should not be deduced from this objection that al-Ghazâlî dismisses immutability and puts it aside. Similarly to Avicenna, he states that there is a general agreement that God is immutable: "We admit that He knows things by one knowledge in the eternal past and future, [His] state never changing. By saying their purpose is to deny change [in God], and on this, there is an agreement" (Al-Ghazâlî 2000: 139). Traditionally, it has been a consensus among different approaches to the nature of God on the doctrine of immutability (Aydeniz 2021: 354, Davidson 1987: 76, Hillier 2005: 76, McGinnis 2010: 178). Briefly stated, it should be emphasized that the 
point al-Ghazâlî opposes is not the attribute of immutability, but the interpretation of God's omniscience in a universal way. ${ }^{4}$

So, what is the problem with affirming that God knows everything in a universal way? According to al-Ghazâlî, Avicenna's thesis restricts knowledge of God to universal concepts and forms, while preventing Him from knowing beings and facts associated with change, time, and tenses. If one acknowledges Avicenna's thesis, for example, they will have to accept that God knows the concept of man and the qualities associated with man, but He is unaware of particular individuals who came into existence. Similarly, God will not know which individual believes in Him or which one rebels against Him (Acar 2004: 145, Al-Ghazâlî 2000: 136-137). Because in order to know these, it is necessary to know tensed facts and the change in $t 1$ such as ' $x$ doesn't believe me now' and ' $x$ believes me now' in $t 2$. However, since knowledge of tensed facts is excluded from omniscience in Avicenna's thesis, it seems difficult for God to be aware of the events going on in the universe.

As shown in the earlier quote, according to al-Ghazâlî, the knowledge expressed in different tenses differs from each other. For example, tensed expressions about the same event such as 'The sun will become eclipsed tomorrow' and 'The sun is becoming eclipsed now' are different in meaning. Because if these expressions had the same meaning, there would be no problem in saying 'The sun will become eclipsed tomorrow' during a solar eclipse. However, someone who says that the sun will become eclipsed tomorrow while the sun is becoming eclipsed is ignorant about the subject (Al-Ghazâlî 2000: 134-135). Therefore, according to al-Ghazâlî, it is not possible to characterize a being who is ignorant of such tensed facts as omniscient. It seems necessary for God to know tensed facts to be qualified as omniscient.

So, what is al-Ghazâlî's thesis on the subject? Basically, he argues that God's knowledge must contain everything, including tensed facts. According to his thesis, omniscience requires God to know the facts about the universe expressed in tenses such as the future, present, and past. Otherwise, it is not possible to qualify a being who does not know these facts as an omniscient. Of course, when we take tensed facts that imply change for God into the extent of omniscience, we return to the tension between omniscience and immutability that we have put forward above. Accordingly, al-Ghazâlî, on the one hand, defends the doctrine of immutability as Avicenna, on the other hand, claims that He knows tensed facts which are a problem for this doctrine.

Then, how does al-Ghazâlî overcome the tension between omniscience and immutability? Al-Ghazâlî's solution to the problem is to claim that real change occurs in tensed facts or in the universe, while God is only subject to relational change by knowing them. He expresses this in the following words:

"With what [argument] do you deny one who says that God, exalted be $\mathrm{He}$, has one knowledge of the existence of the eclipse, for example, at a specific time; and that this [same] knowledge before [the existence

4 Al-Ghazâlî admits that God is immutable, not only in the context of omniscience, but also other attributes (see Frank 1992: 84, Madelung 2015; 28, Marmura 2005: 148-149). 
of the eclipse] is the knowledge that it will be, being identical with the knowledge at the time of the eclipse and identical with the knowledge after the clearing [of the eclipse]; and that these differences reduce to relations that do not necessitate a change in the essence of knowledge and, hence, do not necessitate a change in the essence of the knower; and that [these differences] have the status of a pure relation?" For, [in moving past you, an] individual [is first] on your right, [then] moves on to be in front of you and then [moves] to your left. The relations thus succeed each other for you; but the one changing is that moving individual, not yourself. This is how the state of affairs ought to be understood as regards God's knowledge. For we admit that He knows things by one knowledge in the eternal past and future, [His] state never changing (Al-Ghazâlî 2000: 138-139).

We can say that al-Ghazâlî has two main claims in this quote. The first claim is that no real change occurs in God by knowing tensed facts. According to al-Ghazâlî, there is only one knowledge about the solar eclipse that falls within the extent of God's knowledge. Besides, the solar eclipse happening in the future, now, or in the past is a change or a succession in the universe. This does not mean any change in God or His knowledge. Thus, true or real change takes place in the universe within time, and God is only subject to relational change as He is associated with it. There is no problem with a relational change in God because it does not mean real change. ${ }^{5}$ The second claim, similar to Avicenna, is that God knows everything by one knowledge. According to al-Ghazâlî, He knows the universe, which is in change, without changing Himself with this one knowledge (Griffel 2009: 191-192, Tanış 2018: 107).

To evaluate al-Ghazâlî's claims regarding immutability and omniscience, firstly, we can state that he acknowledges the reality of tensed facts. Accordingly, he claims that our expressions about tensed facts differ in meaning. The fact that they differ in meaning is an indication of their reality. If the propositions we express as tensed were to have the same meaning, it would be possible to express them tenselessly. Secondly, because al-Ghazâlî adheres to the reality of tensed facts, he claims that God must know tensed facts in order to be omniscient. God cannot be omniscient without knowing them. Thirdly, he solves the tension between God's knowledge of tensed facts and immutability by suggesting that $\mathrm{He}$ is only subjected to a relational change by knowing these facts. Accordingly, only the being in time is subject to real change, and God does not undergo any real change by knowing this. Rather, God changes only relationally since He has a relationship with this being in time.

Is al-Ghazâlî's solution to the tension persuasive? It is hard to say it is so for two reasons. First, on the one hand, he stresses that as tensed facts differ in meaning, God must know them in a tensed way to be omniscient. But on the other hand, he seems to contradict himself by arguing that knowledge of tensed facts is one knowledge for God. It is not consistent to say that our expressions about tensed facts have different

\footnotetext{
5 In contemporary philosophical literature, the concept of 'Cambridge Change' is used to express such unreal changes (See Geach 1972: 321-322).
} 
meanings and that God must know each of them to be omniscient, and to claim that what is expressed by tensed facts is in fact one knowledge.

We can easily show this from an example given by al-Ghazâlî. Suppose $x$ will come home tomorrow at sunrise. According to al-Ghazâlî, there is a one knowledge that one needs to know since there is only one fact here. However, this knowledge can be expressed in different tenses such as ' $x$ will come tomorrow', ' $x$ is coming now' and ' $x$ came yesterday'. Therefore, when we know the one knowledge about the arrival of $x$, this knowledge includes all the cases expressed in different tenses (Al-Ghazâlî 2000: 139, 2013: 146-147). But if knowing a single fact is enough to know everything that is expressed in a tensed way, then why does al-Ghazâlî argue at the beginning of discussion that tensed facts have different meanings and that God must know each of them to be omniscient? While at the beginning of discussion, al-Ghazâlî acknowledges the reality of tensed facts by saying that God must know every tensed fact to be omniscient, at the end of discussion he disproves their reality by arguing that all knowledge expressed in different tenses is one knowledge for God.

Second and the main reason why al-Ghazâlî's solution is not convincing is that he cannot provide any justification for the claim he put forward. That is to say, he claims that both God knows all tensed facts and that His knowledge consists of one unchanging knowledge. So, how is this possible? Al-Ghazâlî seems to be aware that he can be criticized in this respect and says that the same criticism can be directed to Avicenna. Accordingly, Avicenna claims that God knows all genera and species with one knowledge. However, knowledge of genera and species leads to a multiplicity in His substance. In this case, al-Ghazâlî argues, if God knows the multiple genera and species with one knowledge, then why doesn't He know tensed facts, that is, knowledge of the past, present, and future, with one knowledge? (Al-Ghazâlî 2000: 140) Of course, this answer contains tu quoque fallacy since, instead of justifying his claim, al-Ghazâlî defends himself by arguing that his opponents have made the same claim.

\section{Conclusion}

Regarding the tension between omniscience and immutability, Islamic philosophers have discussed the problem in detail through knowledge of tensed facts, and tried to provide a reconciliation between these attributes. Since Avicenna accepts the reality of tensed facts, he argues that God will undergo change by knowing them, and as a result, he tries to solve the problem by claiming that He does not know tensed facts. He thinks that immutability is more fundamental to God's perfection than omniscience, and therefore he excludes knowledge of tensed facts, which undermines immutability, from the extent of God's knowledge. However, by claiming that God knows everything in a universal way, he suggests that everything indirectly falls within the extent of this absolute knowledge. In sum, he argues that not knowing tensed facts directly is compatible with omniscience. Considered in 
terms of logical consistency, this solution may seem reasonable at first glance. So, if tensed facts are real, then by knowing them God will be subject to change. In this case, it may be reasonable to exclude tensed facts from the extent of God's knowledge to preserve His immutability and say that He knows them in a universal way. However, this solution, while trying to preserve immutability, considerably undermines omniscience and eliminates God's knowledge of tensed facts. In this way, it creates an understanding of God that is hard to accept from the theistic point of view.

Unlike Avicenna, al-Ghazâlî claims that based on the reality of tensed facts, a being that does not know them cannot be regarded as omniscient. Therefore, God must know tensed facts. Besides this, he argues that God is immutable, similar to Avicenna. He makes a distinction between real and relational change to explain how God, who knows tensed facts, is not subject to change. According al-Ghazâlî, beings that live in time are subject to real change, while God is only subject to relational change due to being associated with these beings. But this solution is inconsistent. That is to say, on the one hand, when al-Ghazâlî criticizes Avicenna, he claims that the knowledge expressed by tensed facts is different from each other and that God must know each of them to be omniscient. On the other hand, since he affirms immutability, he is forced to argue that knowledge of tensed facts consists of one knowledge for God and therefore He is not subject to change. As it is seen, while al-Ghazâlî initially argues that God must know tensed facts based on the reality of tensed facts, he refuses the reality of them in terms of his conclusion. Based on this, we can say he commits an inconsistency in his solution.

\section{Acknowledgments}

I would like to thank Mehmet Altınışık and Nesim Aslantatar for their helpful comments and suggestions.

Address:

Abdulkadir Tanış

Mimar Sinan Mahallesi 3. Cadde No: 1

Hitit University

Çorum, Turkey

E-mail: abdulkadirtanis@hitit.edu.tr

\section{References}

Acar, R. (2004) “Reconsidering Avicenna's position on God's knowledge of particulars". In Jon McGinnis, ed. Interpreting Avicenna: science and philosophy in Medieval Islam, 142-156. (Proceedings of the Second Conference of the Avicenna Study Group.) Leiden: Brill.

Adamson, P. (2005) “On knowledge of particulars". Proceedings of the Aristotelian Society 105, 257278. 
Adamson, P. (2016) Philosophy in the Islamic world: a history of philosophy without any gaps. Oxford: Oxford University Press.

Afnan, S. M. (2016) Avicenna: his life and works. London and New York: Routledge Taylor \& Francis Group.

Al-Ghazâlî, Abu Muhammad (1980) "Al-Munqidh min al-Dalâl". In Freedom and fulfillment: an annotated translation of al-Ghazâlî's al-Munqidh min al-Dalâl and other relevant works of al-Ghazâlî, 61-114. Richard J. McCarthy, transl. Boston: Twayne Publishers.

Al-Ghazâlî, Abu Muhammad (2000) The incoherence of the philosophers. Michael E. Marmura, transl. Provo, Utah: Brigham Young University Press.

Al-Ghazâlî, Abu Muhammad (2013) Moderation in belief. Aladdin M. Yaqub, transl. Chicago: University of Chicago Press.

Avicenna (2005) The metaphysics of the healing. Michael E. Marmura, transl. Provo, Utah: Brigham Young University Press.

Avicenna (2009) The physics of the healing. Jon McGinnis, transl. Provo, Utah: Brigham Young University Press.

Avicenna (2014) [Ibn Sina's] Remarks and admonitions: physics and metaphysics. An analysis and annotated trans. Shams Inati. New York: Columbia University Press.

Aydeniz, H. (2021) “Molla Sadrâ'da Allah’ı bilmenin imkânı ve O’nun hakkında konuşmanın sınırları”. Hitit Ilahiyat Dergisi 20, 1, 347-376.

Burrell, D. B. (1986) Knowing the unknowable God: Ibn-Sina, Maimonides, Aquinas. Notre Dame, Indiana: University of Notre Dame Press.

Campanini, M. (2019) Al-Ghazâlî and the divine. London and New York: Routledge Taylor \& Francis Group.

Comrie, B. (1985) Tense. Cambridge: Cambridge University Press.

Craig, W. L. (2000) "Omniscience, tensed facts, and divine eternity". Faith and Philosophy 17, 2, 225-241.

Davidson, H. A. (1987) Proofs for eternity, creation and the existence of God in Medieval Islamic and Jewish philosophy. Oxford: Oxford University Press.

Dyke, H. (2013) "Time and tense". In H. Dyke and A. Bardon, eds. A companion to the philosophy of time, 328-344, Malden: Wiley-Blackwell.

Fakhyr, M. (2004) A history of Islamic philosophy. 3rd ed. New York: Columbia University Press.

Frank, R. M. (1992) Creation and the cosmic system: Al-Ghazâli \& Avicenna. Heidelberg: C. Winter Universitätsverlag.

Geach, P. T. (1972) Logic matters. Oxford: Basil Blackwell.

Griffel, F. (2009) Al-Ghazali's philosophical theology. Oxford: Oxford University Press.

Hillier, H. C. (2005) "Al-Ghazali's argument for the eternity of the world in Tahafut al-falasifa (discussion one, proofs 1 and 2a) and the problem of divine immutability and timelessness". Journal of Islamic Philosophy 1, 1, 62-84.

Kretzmann, N. (1966) “Omniscience and immutability”. The Journal of Philosophy 63, 14, 409-421.

Leaman, O. (2004) An introduction to classical Islamic philosophy. Cambridge: Cambridge University Press.

Leftow, B. (2016) "Immutability". Edward N. Zalta, ed.The Stanford encyclopedia of philosophy, Available online at <https://plato.stanford.edu/archives/win2016/entries/immutability/>. Accessed on 04.12.2020. 
Madelung, W. (2015) “Al-Ghazâlî’s changing attitude to philosophy”. In Georges Tamer, ed. Islam and rationality: the impact of Al-Ghazâlî. (Papers collected on his 900th anniversary), 23-34. Leiden and Boston: Brill.

Marmura, M. E. (1962) "Some aspects of Avicenna's theory of God's kKnowledge of particulars". Journal of the American Oriental Society 82, 3, 299-312.

Marmura, M. E. (1985) "Divine omniscience and future contingents in Alfarabi and Avicenna". In Tamar Rudavsky, ed. Divine omniscience and omnipotence in Medieval philosophy: Islamic, Jewish and Christian perspectives, 81-94. Dordrecht u. a.: Reidel.

Marmura, M. E. (2005) "Al-Ghazâlı”. In Peter Adamson and Richard C. Taylor, eds The Cambridge companion to Arabic philosoph, 32-51. Cambridge: Cambridge University Press.

McGinnis, J. (2010) Avicenna. Oxford: Oxford University Press.

McTaggart, J. E. (1908) “The unreality of time”. Mind 17, 68, 457-474.

Swinburne, R. (1990) “Tensed facts”. American Philosophical Quarterly 27, 2, 117-130.

Tanış, A. (2018) “Gazâli’de Tanrı'nın Değişmezliği ve Mutlak İlmi”. In M. N. Doru and Ömer Bozkurt, eds. Düşünce bilimleri: klasik sorunlar-güncel tartışmalar, 97-111. Mardin: Mardin Artuklu Üniversitesi Yayınları.

Tegtmeier, E. (2014) “Temporal succession and tense". In L. Nathan Oaklander, ed. Debates in the metaphysics of time, 73-85. London: Bloomsbury. 